\title{
Understanding microplastics in aquatic ecosystems - A mini review
}

\author{
Chen-Lin Soo ${ }^{*}$, Shahirah Sabana ${ }^{1}$, Cheng-Ann Chen ${ }^{2}$ and Yii-Siang Hii ${ }^{3}$ \\ 1 Institute for Tropical Biology and Conservation, Universiti Malaysia Sabah, Jalan UMS, 88400 Kota Kinabalu, \\ Sabah, Malaysia \\ ${ }^{2}$ Borneo Marine Research Institute, Universiti Malaysia Sabah, Jalan UMS, 88400 Kota Kinabalu, Sabah, Malaysia \\ 3 Pakar Scieno Tw Sdn. Bhd., 25, Jalan Pengacara U1/48, Temasya Industrial Park, Section U1, 40150 Shah Alam, \\ Selangor Darul Ehsan, Malaysia
}

*Corresponding author: soo@ums.edu.my

\begin{abstract}
Microplastic is defined as plastic debris with a size less than $5 \mathrm{~mm}$. It is characterized based on colour, shape, and polymer type. Microplastics have been discovered in a variety of aquatic environments, including freshwater, estuarine, and marine waters. The presence of microplastic in aquatic systems poses a threat not only to aquatic organisms, but to human consumers of food harvested from these environments. This paper reviews the key characteristics of microplastics, how they contaminate aquatic ecosystems, and their effects on aquatic organisms. Efforts have been made to highlight the knowledge gaps in these areas and measures that deserve attention for addressing the problem.
\end{abstract}

Keywords: Microplastics, Aquatic organisms, Trophic transfer, Consumer health, Possible measures

\section{Background}

With the passage of time, the world entered the Plastic Age, and we now live in a plastic-filled world (Thompson et al., 2009). Plastic is now ubiquitous in our daily lives and products, resulting in an estimated 12,000 Mt of plastic waste in landfills and the natural environment by 2050 (Geyer et al., 2017). Plastic has become the preferred material due to its numerous advantages, such as low cost, durability, and lightweight. All of these accolades for plastic, however, are the same factors that contribute to its hasty disposal and, as a result, detrimental environmental consequences (Adane and Muleta, 2011; Lebreton and Andrady, 2019).

Microplastic is defined as plastic trash with a diameter of less than 5 millimetres (Frias and Nash, 2019; GESAMP, 2015). Microplastic is derived from primary sources, such as microbeads in personal care and cosmetic products (Guerranti et al., 2019), or secondary sources by breakdown of bigger plastic trash into numerous smaller debris under the action of physical, chemical and biological processes (Efimova et al., 2018; Zhang et al., 2021). One of the most prominent anthropogenic aspects of microplastic pollution is the improper disposal of plastic trash, which has accelerated the accumulation of microplastics in aquatic environments (Geyer et al., 2017). Plastics that are broken down into micro particles can easily spread into fresh and marine aquatic habitats (Firdaus et al., 2020; Li et al., 2021; Bharath et al., 2021; Napper et al., 2021), creating difficult problems.
In recent years, the issue of microplastic has come to the forefront of global attention, leading to studies on different aspects of microplastic pollution that suggest that there is a potential hazard for water quality, aquatic life (Anbumani and Kakkar, 2018; Jahan et al., 2019; Naqash et al., 2020; Rezania et al., 2018) and human health (Gabriel et al., 2018; Karbalaei et al., 2018). Microplastics are frequently mistaken for prey by many aquatic organisms and the trophic transfer creates serious consequences that are a matter of global concern (Athey et al., 2020; da Costa Araújo et al., 2020; Dong et al., 2021; Huang et al., 2021). This mini review aims to provide the key information on microplastic characteristics and how it affects the aquatic ecosystems. The knowledge gaps that have been identified provide ideas for pursuing research to understand the severity of the problem and managing it as effectively as possible.

\section{Microplastic characteristics}

Microplastics, like other pollutants, have unique properties that influence their long-term fate in the environment. Typically, there are four characteristics of microplastics, namely, sizes, colours, shapes, and polymer types. Researchers classify microplastics into various size groups in order to study their size distribution (Edo et al., 2020; Sathish et al., 2020; Zhou et al., 2021). The size classification is important to avoid confusion between microplastic and nanoplastic, which are both produced by plastic fragmentation. Nanoplastic has been classified as having a size range of $1 \mathrm{~nm}$ to $1 \mu \mathrm{m}$ (Gigault et al., 2018), whereas microplastic has a size range of $1 \mu \mathrm{m}$ to $500 \mu \mathrm{m}$ (Frias and Nash, 2019). Microplastic size affects its abundance, with the smallest size being the most 
abundant, and that as the size increases, the abundance of microplastic decreases (Lots et al., 2017; Yaranal et al., 2021). Smaller-sized microplastics often pose a greater threat to the aquatic organisms than larger-sized microplastics (Choi et al., 2020).

Microplastic colours are commonly classified as transparent, white, black, and others such as yellow, red, blue, and green. White and transparent microplastics dominated on Indian beaches and in the influent and effluent of wastewater treatment plants in China (Long et al., 2019; Yaranal et al., 2021). Coloured microplastics, on the other hands, have been discovered in the Ganges River, with blue being the most prevalent colour (Napper et al., 2021). Coloured microplastic sinks more easily into the water column than white or transparent microplastic due to the presence of pigments, which add weight to it (Zhou et al., 2021). Microplastic colour is important in aquatic ecosystem because the product may be mistaken for food by aquatic organisms by virtue of its colour.

Microplastics has been categorized into various basic shapes such as fragments, fibres, films, foams, and beads. Most of the time, fibres were found to be the most prevalent microplastic shape type (Firdaus et al., 2020; Li et al., 2021; Napper et al., 2021). Many studies have reported that fragment types can dominate aquatic environments (Baini et al., 2018; Khalik et al., 2018; Yaranal et al., 2021). Microplastics in the form of foam materials are abundant near mariculture sites (Zhou et al., 2020). Typically, the bead type is the least of all or may even be non-existent in many aquatic environments because it is mostly derived from primary sources. It is commonly used in personal care and cosmetics but has been banned in a number of countries (Free et al., 2014). Other shapes of microplastics are secondary microplastics that originate from the breakdown of larger macro-debris from textiles, plastic bags, packaging material, and other consumer products (Salvador et al., 2017; Falco et al., 2018; Townsend et al., 2019; Lant et al., 2020). Evidently, the shape of microplastics can help identify their origin from primary or secondary sources.

Microplastics are man-made long-chain polymeric materials that are classified based on the polymer type. Microplastic density varies and has an impact on its distribution in aquatic systems. Polyethylene (PE) and polypropylene (PP) tend to float because their density is lower than that water. Polystyrene (PS), polyvinyl chloride (PVC), polyamide (nylon) (PA), and polyethylene terephthalate (PET) are denser than water and tend to sink (Guo and Wang, 2019). In aquatic environments, PE, PP, and PS are the most frequently found polymers (Efimova et al., 2018). PE and PP commonly occur in surface waters and sediments along the Pearl River in Guangzhou, China (Lin et al., 2018). PE is commonly used in plastic bags for packaging, whereas PP fibres are widely used in ropes, nonwoven fabrics, air filters, diapers, and fishing nets (Nor and
Obbard, 2014; Yaranal et al., 2021). When discarded, these products become a source of microplastic.

\section{Microplastics in Aquatic Ecosystems}

Microplastics have been found to contaminate a wide range of waterbodies, with their occurrence and abundance varying according to the intensity of human activities and waste management systems (Free et al., 2014; Townsend et al., 2019). Direct discharge of domestic waste and industrial drainage, and waste treatment plans are the well-known routes of microplastic to aquatic environments (Estahbanati and Fahrenfeld, 2016). Microplastics collected in drainage systems and wastewater treatment plants can reach a density as high as 68-910 particles per litre (Leslie et al., 2017). A large amount of microplastic is released into the receiving water because some drainage systems are not designed to remove these particles and treatment plants are not always effective in removal of microplastics before discharging this product into aquatic systems (Magni et al., 2019; Mak et al., 2020). In addition, a substantial proportion of microplastics is retained in sludge after wastewater treatment (Leslie et al., 2017; Magni et al., 2019). Soil amendment with sludge becomes a major source of microplastics in agricultural soils and a possible cause of microplastic contamination in aquatic systems via surface runoff (Corradini et al., 2019; Edo et al., 2020; Gao et al., 2020). Extreme weather events such as hurricanes, floods, and storms aggravate the transport of plastic trash from land to aquatic bodies, as seen by higher microplastics in Mexican urban-overdeveloped beaches when extreme weather events occur (AlvarezZeferino et al., 2020).

Microplastics in freshwater systems are transported and deposited in the coastal and marine environments due to the high unidirectional flow of freshwater. In fact, rivers serve as a primary channel for both macro- and microplastic transit into the sea, which accounts for more than $80 \%$ of the total plastic load in the marine environment (Schmidt et al., 2017). Estuaries connect freshwater and marine water, and often become microplastic transfer pathway from river to sea. They are also prone to accumulation of microplastics as they have long been regarded to be a sink for sediments and pollutants (Eulie et al., 2018). Estuaries are microplastic pollution hotspot where microplastics comprised more than $90 \%$ of total number plastics (Fok and Cheung, 2015; Zhao et al., 2015). Microplastic can also be directly transported into the marine environment via coastal tourism and recreation, commercial fishing, and marine industries, as well as direct dumping into the ocean. Coastal tourism and recreation have contributed to a rise in the amount of plastics thrown along beaches and coastal resorts. These eventually enter the ocean and accumulate there (Lozoya et al., 2016). Commercial fishing, on the other hand, increases the amount of microplastic in the ocean since fishing gear is frequently discarded or is lost (Andrady, 2011). 
Microplastic can also invade mangrove forest areas, which are found primarily in the intertidal zone at the confluence of land and sea. Mangrove root systems are known to trap litter, and microplastic particles have been found adhering to mangrove trunks (Garcés-Ordóñez et al., 2019; Li et al., 2018). Plastic sources in the mangrove area, like in other aquatic systems, come from the community waste disposal and direct dumping into the drainage system. Most abundant quantities of microplastic in mangrove areas found near urban and industrial zones (Maghsodian et al., 2021), tourist attractions and near mariculture sites (Zhou et al., 2020). The widespread use of consumer plastic products such as bottles and fishing-related materials such as line and film, contributed to a high level of microplastic pollution in many mangrove habitats (Nor and Obbard, 2014). Even if plastic waste is not disposed directly in the mangrove area, it can be carried away by the water current and get trapped there.

\section{Effect of Microplastic on Aquatic Organisms}

Microplastic has an impact on aquatic organisms through a variety of mechanisms, including direct ingestion, indirect ingestion (trophic transfer), and physical adherence. Direct ingestion is linked to feeding habits of aquatic organisms and preferences. Species with selective feeding habits are less likely to consume microplastics than species exhibiting generalist feeding habits (Mizraji et al., 2017; Peters et al., 2017). Besides, species that prey on larger mesozooplankton consumed more microplastics than the species that feed on smaller plankton (Lopes et al., 2020). Direct ingestion of microplastic by aquatic organisms is common due to their mistaking microplastic for prey. Many aquatic organisms, such as zooplankton, zooplanktivores, fish larvae, and planktivorous fish, are at risk from direct ingestion of microplastics, which are similar in size and resemble in appearance to natural food items. For example, Amberstripe scad (Decapterus muroadsi) ingests microplastics because these particles resemble their copepod prey. The fish consumed mostly blue polyethylene microplastic fragments that were similar in size and colour to their blue copepod prey (Ory et al., 2017). Blue is the most commonly ingested microplastic colour (Lopes et al., 2020; Ory et al., 2017; Sarijan et al., 2019; Steer et al., 2017). Red microplastics, on the other hand, have been found to be more prevalent in fish whose diet consists of red algae (Mizraji et al., 2017), whereas black microplastics have been found to be abundant in oysters and mudskipper fish (Jahan et al., 2019; Maghsodian et al., 2021). Microplastic ingestion has also been recorded in submerged carnivorous plants, where microplastics were ingested by the bladders ( $\mathrm{Yu}$ et al., 2020a). The adverse effects of microplastics have been examined in laboratories. Reduced feeding is one such effects and it is concentration-dependent (Cole et al., 2015; Yu et al., 2020b). Microplastics damage the organs (Caccamo et al., 2016; Lei et al., 2018; Yang et al., 2020), affect the growth, survival, and fecundity (Cole et al.,
2015; Welden and Cowie, 2016; Yu et al., 2020b), and potentially reduce the population growth (Shore et al., 2021). Microplastic consumption also harms wild fish health, as evidenced by lower condition factors $(\mathrm{K})$ of omnivorous fish specimens with higher microplastic content collected from several upper tidal pools in Las Cruces, Chile's central coast (Mizraji et al., 2017).

Microplastics are ingested indirectly by aquatic organisms at higher trophic levels when they eat prey that has previously consumed microplastics. After feeding zooplankton labelled with ingested microplastics, mysid intestine showed the presence of zooplankton prey and microplastics, indicating the trophic transfer of microplastics in the planktonic food web (Setälä et al., 2014). Microplastic transfer along the aquatic food chains causes different impacts on aquatic organisms. It can resulted in mutagenic and cytotoxic effects in Danio rerio adult fish after they were fed Poecilia reticulata fry that had previously ingested microplastics (da Costa Araújo et al., 2020). Microplastics have been shown to adsorb chemical pollutants from their surroundings, with a high sorption capacity for hydrophobic organic pollutants and heavy metals (Gao et al., 2019; Zhang et al., 2020). When combined with existing toxic plastic additives, these compounds pose potential ecotoxicological risks to a variety of aquatic organisms (Klein et al., 2021; Luo et al., 2019; Zimmermann et al., 2020). The potential effects of bioaccumulation and biomagnification of microplastics and associated chemical pollutants and additives are a matter of major concern (Alava, 2020; Saley et al., 2019), even though the evidence for microplastic bioaccumulation and biomagnification via aquatic food chains remains uncertain and unpredictable (Huang et al., 2021). According to Chagnon et al. (2018), even if microplastic is transferred from prey to predatory fish, it will not accumulate in the relatively large digestive tract of large predators. Furthermore, most aquatic organisms egest or excrete the majority of ingested microplastics (Christian et al., 2018; Woods et al., 2018; Xiong et al., 2019). Wang et al. (2021) suggested that biomagnification did not occur after the predatory marine crab (Charybdis japonica) consumed microplasticcontaminated mussels, possibly due to the crab's ability to egest microplastics.

Another way that microplastics contaminate aquatic organisms is through absorption or adherence. Kolandhasamy et al. (2018) found that adherence of microplastics to soft tissue of mussels accounted for about half of the microplastic uptake in mussels. Microplastics were also found on the skin and muscles of fish, as well as several body parts of copepods, implying that adherence is one of the possible routes for microplastic contamination of aquatic organisms (Abbasi et al., 2018; Feng et al., 2019; Benny et al., 2020; Yu et al., 2020b). In aquatic systems, microplastics primarily adhere to the surface of primary producers, limiting the amount of light available to the cells (Yu et al., 2020a). 
Microplastics can also harm microalgae cell membranes, reducing the their photosynthetic activity (Li et al., 2020). When microplastics bind to the surface of the roots of a floating freshwater plant, the length of the roots shortens, indicating the root growth limitation (Kalcikova et al., 2017). Adherence appears to be the most important strategy for trapping microplastics in macroalgae, and morphology, such as the presence of phaeophycean hairs and the stickiness of the macroalgae's surface that played an important role in adherence (Feng et al., 2020). Microplastics have also been seen adhering to the seagrass (Datu and Tahir, 2019) but there is not enough scientific data on its effects on the eco-physiological functions of this important marine flowering vegetation.

\section{Conclusion}

This study summarizes current understanding about microplastics in aquatic ecosystems, including their characteristics, occurrence, and impacts. Microplastics (plastic debris $<5 \mathrm{~mm}$ ) appears in aquatic systems in a variety of sizes, colours, shapes, and polymer types. Many studies on the occurrence and distribution of this pollutant in aquatic ecosystems have been conducted. Microplastics contaminate a wide range of water bodies. Direct discharge from drainage systems and wastewater treatment plants is the most common way microplastic enters aquatic systems. There is an urgent need to upgrade the existing wastewater treatment plants to boost microplastic removal efficiency. Considering the current stage of microplastic pollution, a microplastic water quality standard should be established, along with improved and standardised monitoring of this pollutant. Microplastic modelling is a useful tool for optimising microplastic management that deserves more attention. Monitoring and modelling of microplastics is crucial not only for gaining a better understanding of the issue, but also for validating the pollutant's effects, and raising public awareness.

Microplastics contaminate aquatic organisms through direct ingestion, indirect ingestion (trophic transfer), and physical adherence. Numerous laboratory experiments have shown that microplastic has negative effects on a variety of aquatic organisms. However, more research on microplastic effects is needed to avoid misinterpretation of non-environmentally realistic data and to better assess the potential risk of microplastics to aquatic ecosystems. Microplastics contamination of aquatic organisms poses a risk to human health through food chains. These consequences of microplastic pollution warrant global efforts towards combating the problem of plastic pollution.

\section{Acknowledgements}

The authors would like to thank the Universiti Malaysia Sabah (UMS) for funding this study through Acculturation Grant Scheme (SGA0099-2019).

\section{References}

Abbasi, S., Soltani, N., Keshavarzi, B., Moore, F., Turner, A., and Hassanaghaei, M. (2018). Microplastics in different tissues of fish and prawn from the Musa Estuary, Persian Gulf. Chemosphere 205, 80-87. https://doi.org/10.1016/j.chemosphere.2018.04.076

Adane, L., and Muleta, D. (2011). Survey on the usage of plastic bags, their disposal and adverse impacts on environment: A case study in Jimma City, Southwestern Ethiopia. Journal of Toxicology and Environmental Health Sciences 3(8), 234-248. https://doi.org/10.1080/15287399309531713

Alava, J.J. (2020). Modeling the Bioaccumulation and Biomagnification Potential of Microplastics in a Cetacean Foodweb of the Northeastern Pacific: A Prospective Tool to Assess the Risk Exposure to Plastic Particles. Frontiers in Marine Science 7, 566101. https://doi.org/10.3389/fmars.2020.566101

Alvarez-zeferino, J.C., Ojeda-benítez, S., Cruz-salas, A.A., Martínezsalvador, C., and Vázquez-morillas, A. (2020). Microplastics in Mexican beaches. Resources, Conservation and Recycling 155, 104633. https://doi.org/10.1016/j.resconrec.2019.104633

Anbumani, S., and Kakkar, P. (2018). Ecotoxicological effects of microplastics on biota: a review. Environmental Science and Pollution Research 25, 14373-14396.

Andrady, A.L. (2011). Microplastics in the marine environment.
Marine Pollution $\quad$ Bulletin 62 ,
https://doi.org/10.1016/j.marpolbul.2011.05.030

Athey, S.N., Albotra, S.D., Gordon, C.A., et al. (2020). Trophic transfer of microplastics in an estuarine food chain and the effects of a sorbed legacy pollutant. Limnology and Oceanography Letters, 5(1), 154162. https://doi.org/10.1002/lol2.10130

Baini, M., Cristina, M., Galli, M., et al. (2018). Abundance and characterization of microplastics in the coastal waters of Tuscany (Italy): The application of the MSFD monitoring protocol in the Mediterranean Sea. Marine Pollution Bulletin 133, 543-552. https://doi.org/10.1016/j.marpolbul.2018.06.016

Benny, D., Ashraf, P.M., and Thomas, S. N. (2020). Microplastics in the edible and inedible tissues of pelagic fishes sold for human consumption in Kerala, India. Environmental Pollution 266, 115365. https://doi.org/10.1016/j.envpol.2020.115365

Caccamo, L., Cristina, M., Gai, F., et al. (2016). Intestinal alterations in European sea bass Dicentrarchus labrax (Linnaeus, 1758) exposed to microplastics: Preliminary results. Environmental Pollution 212, 251256. https://doi.org/10.1016/j.envpol.2016.01.083

Chagnon, C., Thiel, M., Antunes, J., et al. (2018). Plastic ingestion and trophic transfer between Easter Island flying fish (Cheilopogon rapanouiensis ) and yellowfin tuna (Thunnus albacares) from Rapa Nui (Easter Island). Environmental Pollution 243, 127-133. https://doi.org/10.1016/j.envpol.2018.08.042

Choi, J.S., Hong, S.H., and Park, J.W. (2020). Evaluation of microplastic toxicity in accordance with different sizes and exposure times in the marine copepod Tigriopus japonicus. Marine $\begin{array}{lll}\text { Environmental } & \text { Research, 153, } & 104838 .\end{array}$ https://doi.org/10.1016/j.marenvres.2019.104838

Christian, N., Gallardo, C., Lenz, M., and Thiel, M. (2018). Capture, swallowing, and egestion of microplastics by a planktivorous juvenile fish. Environmental Pollution 240, 566-573. https://doi.org/10.1016/j.envpol.2018.04.093

Cole, M., Lindeque, P., Fileman, E., et al. (2015). The impact of polystyrene microplastics on feeding, function and fecundity in the marine copepod Calanus helgolandicus. Environmental Science and Technology, 49, 1130-1137. https://doi.org/10.1021/es504525u

Corradini, F., Meza, P., Eguiluz, R., et al. (2019). Evidence of microplastic accumulation in agricultural soils from sewage sludge disposal. Science of the Total Environment 671, 411-420. https://doi.org/10.1016/j.scitotenv.2019.03.368 
da Costa Araújo, A.P., de Andrade Vieira, J.E., and Malafaia, G. (2020). Toxicity and trophic transfer of polyethylene microplastics from Poecilia reticulata to Danio rerio. Science of the Total Environment 742, 140217. https://doi.org/10.1016/j.scitotenv.2020.140217

Datu, S.S., and Tahir, A. (2019). Microplastic in Cymodocea rotundata Seagrass Blades. International Journal of Environment Agriculture and Biotechnology 4(6), 1758-1761.

Dong, Y., Gao, M., Qiu, W., and Song, Z. (2021). Effects of microplastic on arsenic accumulation in Chlamydomonas reinhardtii in a freshwater environment. Journal of Hazardous Materials 405, 124232. https://doi.org/10.1016/j.jhazmat.2020.124232

Edo, C., Gonzalez-Pleiter, M., Leganes, F., et al. (2020). Fate of microplastics in wastewater treatment plants and their environmental dispersion with effluent and sludge. Environmental Pollution 259, 113837. https://doi.org/10.1016/j.envpol.2019.113837

Efimova, I., Bagaeva, M., Bagaev, A., et al. (2018). Secondary microplastics generation in the sea swash zone with coarse bottom sediments: Laboratory experiments. Frontiers in Marine Science 5, 313. https://doi.org/10.3389/fmars.2018.00313

Estahbanati, S., and Fahrenfeld, N.L. (2016). Influence of wastewater treatment plant discharges on microplastic concentrations in surface water. Chemosphere 162, 277-284. https://doi.org/10.1016/j.chemosphere.2016.07.083

Eulie, D.O., Corbett, D.R., and Walsh, J.P. (2018). Shoreline erosion and decadal sediment accumulation in the Tar- Pamlico estuary, North Carolina, USA: A source-to-sink analysis. Estuarine, Coastal and Shelf Science 202, 246-258. https://doi.org/10.1016/j.ecss.2017.10.011

Falco, F. De, Pia, M., Gentile, G., et al. (2018). Evaluation of microplastic release caused by textile washing processes of synthetic fabrics. Environmental Pollution 236, 916-925. https://doi.org/10.1016/j.envpol.2017.10.057

Feng, Z., Zhang, T., Li, Y., et al. (2019). The accumulation of microplastics in fish from an important fish farm and mariculture area, Haizhou Bay, China. Science of the Total Environment 696, 133948. https://doi.org/10.1016/j.scitotenv.2019.133948

Feng, Z., Zhang, T., Wang, J. et al. (2020). Spatio-temporal features of microplastics pollution in macroalgae growing in an important mariculture area, China. Science of the Total Environment 719, 137490. https://doi.org/10.1016/j.scitotenv.2020.137490

Firdaus, M., Trihadiningrum, Y., and Lestari, P. (2020). Microplastic pollution in the sediment of Jagir Estuary, Surabaya City, Indonesia. $\begin{array}{llll}\text { Marine Pollution } & \text { Bulletin } & 10790 .\end{array}$ https://doi.org/10.1016/j.marpolbul.2019.110790

Fok, L., and Cheung, P.K. (2015). Hong Kong at the Pearl River Estuary: A hotspot of microplastic pollution. Marine Pollution Bulletin 99, 112-118. https://doi.org/10.1016/j.marpolbul.2015.07.050

Free, C.M., Jensen, O.P., Mason, S. A., et al. (2014). High-levels of microplastic pollution in a large, remote, mountain lake. Marine Pollution Bulletin 85, 156-163. https://doi.org/10.1016/j.marpolbul.2014.06.001

Frias, J.P.G.L., and Nash, R. (2019). Microplastics: Finding a consensus on the definition. Marine Pollution Bulletin 138, 145-147. https://doi.org/10.1016/j.marpolbul.2018.11.022

Gabriel, L., Barboza, A., Vethaak, A.D., et al. (2018). Marine microplastic debris: An emerging issue for food security, food safety and human health. Marine Pollution Bulletin 133, 336-348. https://doi.org/10.1016/j.marpolbul.2018.05.047

Gao, D., Li, X., and Liu, H. (2020). Source, occurrence, migration and potential environmental risk of microplastics in sewage sludge and during sludge amendment to soil. Science of the Total Environment 742, 140355. https://doi.org/10.1016/j.scitotenv.2020.140355
Gao, F., Li, J., Sun, C., Zhang, L., et al. (2019). Study on the capability and characteristics of heavy metals enriched on microplastics in marine environment. Marine Pollution Bulletin 144, 61-67. https://doi.org/10.1016/j.marpolbul.2019.04.039

Garcés-ordóñez, O., Castillo-olaya, V.A., Granados-briceño, A.F., et al. (2019). Marine litter and microplastic pollution on mangrove soils of the Ciénaga Grande de Santa Marta, Colombian Caribbean. Marine Pollution Bulletin 145, 455-462. https://doi.org/10.1016/j.marpolbul.2019.06.058

GESAMP. (2015). Sources, fate and effects of microplastics in the marine environment: A global assessment (P. Kershaw, ed.). Retrieved from www.imo.org

Geyer, R., Jambeck, J.R., and Law, K.L. (2017). Production, use, and fate of all plastics ever made. Science Advances 3, e1700782.

Guerranti, C., Martellini, T., Perra, G., et al. (2019). Microplastics in cosmetics: Environmental issues and needs for global bans. Environmental Toxicology and Pharmacology 68, 75-79. https://doi.org/10.1016/j.etap.2019.03.007

Guo, X., and Wang, J. (2019). The chemical behaviors of microplastics in marine environment: A review. Marine Pollution Bulletin 142, 1-14. https://doi.org/10.1016/j.marpolbul.2019.03.019

Huang, W., Song, B., Liang, J., et al. (2021). Microplastics and associated contaminants in the aquatic environment: A review on their ecotoxicological effects, trophic transfer, and potential impacts to human health. Journal of Hazardous Materials 405, 124187. https://doi.org/10.1016/j.jhazmat.2020.124187

Jahan, S., Strezov, V., Weldekidan, H., et al. (2019). Interrelationship of microplastic pollution in sediments and oysters in a seaport environment of the eastern coast of Australia. Science of the Total Environment https://doi.org/10.1016/j.scitotenv.2019.133924

Kalcikova, G., Gotvajn, A.Z., Kladnik, A., and Jemec, A. (2017). Impact of polyethylene microbeads on the floating freshwater plant. Environmental Pollution 230, 1108-1115. https://doi.org/10.1016/j.envpol.2017.07.050

Karbalaei, S., Hanachi, P., Walker, T. R., and Cole, M. (2018). Occurrence, sources, human health impacts and mitigation of microplastic pollution. Environmental Science and Pollution Research 25, 36046-36063.

Khalik, W.M.A.W.M., Ibrahim, Y.S., Anuar, S.T., et al. (2018). Microplastics analysis in Malaysian marine waters: A field study of Kuala Nerus and Kuantan. Marine Pollution Bulletin 135, 451-457. https://doi.org/10.1016/j.marpolbul.2018.07.052

Klein, K., Piana, T., Lauschke, T., et al. (2021). Chemicals associated with biodegradable microplastic drive the toxicity to the freshwater oligochaete Lumbriculus variegatus. Aquatic Toxicology 231, 105723. https://doi.org/10.1016/j.aquatox.2020.105723

Kolandhasamy, P., Su, L., Li, J., et al. (2018). Adherence of microplastics to soft tissue of mussels: A novel way to uptake microplastics beyond ingestion. Science of the Total Environment 610-611, 635-640. https://doi.org/10.1016/j.scitotenv.2017.08.053

Lant, N.J., Hayward, A.S., Peththawadu, M.M.D., et al. (2020). Microfiber release from real soiled consumer laundry and the impact of fabric care products and washing conditions. PLoS ONE 15(6), e0233332. https://doi.org/10.1371/journal.pone.0233332

Lebreton, L., and Andrady, A. (2019). Future scenarios of global plastic waste generation and disposal. Palgrave Communications 5(1), 1-11. https://doi.org/10.1057/s41599-018-0212-7

Lei, L., Wu, S., Lu, S., et al. (2018). Microplastic particles cause intestinal damage and other adverse effects in zebra fish Danio rerio and nematode Caenorhabditis elegans. Science of the Total Environment 619-620,1-8. https://doi.org/10.1016/j.scitotenv.2017.11.103 
Leslie, H.A., Brandsma, S.H., Velzen, M.J.M., et al. (2017). Microplastics en route: Field measurements in the Dutch river delta and Amsterdam canals, wastewater treatment plants, North Sea sediments and biota. Environment International 101, 133-142. https://doi.org/10.1016/j.envint.2017.01.018

Li, J., Zhang, H., Zhang, K., et al. (2018). Characterization, source, and retention of microplastic in sandy beaches and mangrove wetlands of the Qinzhou Bay, China. Marine Pollution Bulletin 136, 401-406. https://doi.org/10.1016/j.marpolbul.2018.09.025

Li, J.L., Ouyang, Z., Liu, P., et al. (2021). Distribution and characteristics of microplastics in the basin of Chishui River in Renhuai, China. Science of the Total Environment 773, 145591. https://doi.org/10.1016/j.scitotenv.2021.145591

Li, S., Wang, P., Zhang, C., et al. (2020). Influence of polystyrene microplastics on the growth , photosynthetic efficiency and aggregation of freshwater microalgae Chlamydomonas reinhardtii. Science of the $\begin{array}{lll}\text { Total Environment } & 7136767 .\end{array}$ https://doi.org/10.1016/j.scitotenv.2020.136767

Lin, L., Zuo, L., Peng, J., et al. (2018). Occurrence and distribution of microplastics in an urban river: A case study in the Pearl River along Guangzhou City, China. Science of the Total Environment 644, 375381. https://doi.org/10.1016/j.scitotenv.2018.06.327

Long, Z., Pan, Z., Wang, W., et al. (2019). Microplastic abundance, characteristics, and removal in wastewater treatment plants in a coastal city of China. Water Research 155, 255-265. https://doi.org/10.1016/j.watres.2019.02.028

Lopes, C., Raimundo, J., Caetano, M., and Garrido, S. (2020). Microplastic ingestion and diet composition of planktivorous fish. Limnology and Oceanography Letters 5, 103-112. https://doi.org/10.1002/lol2.10144

Lots, F.A. E., Behrens, P., Vijver, M.G., et al. (2017). A large-scale investigation of microplastic contamination: Abundance and characteristics of microplastics in European beach sediment. Marine Pollution Bulletin 123, 219-226. https://doi.org/10.1016/j.marpolbul.2017.08.057

Lozoya, J., Mello, F., Carrizo, D., et al. (2016). Plastics and microplastics on recreational beaches in Punta del Este (Uruguay): Unseen critical residents? Environmental Pollution 218, 931-941. https://doi.org/10.1016/j.envpol.2016.08.041

Luo, H., Xiang, Y., He, D., et al. (2019). Leaching behavior of fluorescent additives from microplastics and the toxicity of leachate to Chlorella vulgaris. Science of the Total Environment 678, 1-9. https://doi.org/10.1016/j.scitotenv.2019.04.401

Maghsodian, Z., Mohamad, A., Ramavandi, B., et al. (2021). Microplastics accumulation in sediments and Periophthalmus waltoni fish, mangrove forests in southern Iran. Chemosphere 264, 128543. https://doi.org/10.1016/j.chemosphere.2020.128543

Magni, S., Binelli, A., Pittura, L., et al. (2019). The fate of microplastics in an Italian Wastewater Treatment Plant. Science of the Total Environment 652 602-610. https://doi.org/10.1016/j.scitotenv.2018.10.269

Mak, C.W., Tsang, Y.Y., Leung, M.M., et al. (2020). Microplastics from effluents of sewage treatment works and stormwater discharging into the Victoria Harbor, Hong Kong. Marine Pollution Bulletin 157, 111181. https://doi.org/10.1016/j.marpolbul.2020.111181

Manikanda Bharath, K., Srinivasalu, S., Usha, N., Ramamoorthy, A., et al. (2021). Microplastics as an emerging threat to the freshwater ecosystems of Veeranam lake in south India: A multidimensional $\begin{array}{lll}\text { approach. Chemosphere } & 264, & 128502 .\end{array}$ https://doi.org/10.1016/j.chemosphere.2020.128502

Mizraji, R., Ahrendt, C., Perez-venegas, D., et al. (2017). Is the feeding type related with the content of microplastics in intertidal fish gut? Marine Pollution Bulletin 116, 498-500. https://doi.org/10.1016/j.marpolbul.2017.01.008
Napper, I. E., Baroth, A., Barrett, A. C., et al. (2021). The abundance and characteristics of microplastics in surface water in the transboundary Ganges River. Environmental Pollution 274, 116348. https://doi.org/10.1016/j.envpol.2020.116348

Naqash, N., Prakash, S., Kapoor, D., and Singh, R. (2020). Interaction of freshwater microplastics with biota and heavy metals: a review. Environmental Chemistry Letters 18, 1813-1824. https://doi.org/10.1007/s10311-020-01044-3

Nor, N., and Obbard, J. (2014). Microplastics in Singapore' s coastal mangrove ecosystems. Marine Pollution Bulletin 79, 278-283. https://doi.org/10.1016/j.marpolbul.2013.11.025

Ory, N.C., Sobral, P., Joana, F.L., and Thiel, M. (2017). Amberstripe scad Decapterus muroadsi (Carangidae) fish ingest blue microplastics resembling their copepod prey along the coast of Rapa Nui (Easter Island) in the South Pacific subtropical gyre. Science of the Total $\begin{array}{lll}\text { Environment } & \text { 586, 430-437. }\end{array}$ https://doi.org/10.1016/j.scitotenv.2017.01.175

Peters, C.A., Thomas, P.A., Rieper, K.B., and Bratton, S.P. (2017). Foraging preferences influence microplastic ingestion by six marine fi sh species from the Texas Gulf Coast. Marine Pollution Bulletin 124 82-88. https://doi.org/10.1016/j.marpolbul.2017.06.080

Rezania, S., Park, J., Fadhil, M., et al. (2018). Microplastics pollution in different aquatic environments and biota: A review of recent studies. Marine Pollution Bulletin 133, 191-208. https://doi.org/10.1016/j.marpolbul.2018.05.022

Saley, A.M., Smart, A.C., Bezerra, M.F., et al. (2019). Microplastic accumulation and biomagnification in a coastal marine reserve situated in a sparsely populated area. Marine Pollution Bulletin 146, 54-59. https://doi.org/10.1016/j.marpolbul.2019.05.065

Salvador, F., Turra, A., and Baruque-ramos, J. (2017). Synthetic fibers as microplastics in the marine environment: A review from textile perspective with a focus on domestic washings. Science of the Total Environment 598, 1116-1129. https://doi.org/10.1016/j.scitotenv.2017.04.172

Sarijan, S., Azman, S., Mohd Said, M. I., and Lee, M. H. (2019). Ingestion of Microplastics by Commercial Fish in Skudai River, Malaysia. EnvironmentAsia 12(3), 75-84. https://doi.org/10.14456/ea.2019.47

Sathish, M.N., Jeyasanta, K.I., and Patterson, J. (2020). Monitoring of microplastics in the clam Donax cuneatus and its habitat in Tuticorin coast of Gulf of Mannar (GoM), India. Environmental Pollution 266, 115219. https://doi.org/10.1016/j.envpol.2020.115219

Schmidt, C., Krauth, T., and Wagner, S. (2017). Export of Plastic Debris by Rivers into the Sea. Environmental Science and Technology 51, 12246-12253. https://doi.org/10.1021/acs.est.7b02368

Setälä, O., Fleming-lehtinen, V., and Lehtiniemi, M. (2014). Ingestion and transfer of microplastics in the planktonic food web. Environmental Pollution 185, 77-83. https://doi.org/10.1016/j.envpol.2013.10.013

Shore, E.A., James, A., and Pespeni, M.H. (2021). Microplastics reduce net population growth and fecal pellet sinking rates for the marine copepod, Acartia tonsa. Environmental Pollution 284, 117379. https://doi.org/10.1016/j.envpol.2021.117379

Steer, M., Cole, M., Thompson, R.C., and Lindeque, P.K. (2017). Microplastic ingestion in fish larvae in the western English Channel. $\begin{array}{lll}\text { Environmental Pollution 226, 250-259. } & \text { 20 }\end{array}$ https://doi.org/10.1016/j.envpol.2017.03.062

Thompson, R.C., Swan, S.H., Moore, C.J., and Vom Saal, F.S. (2009). Our plastic age. Philosophical Transactions of the Royal Society B: Biological Sciences 364(1526), 1973-1976. https://doi.org/10.1098/rstb.2009.0054

Townsend, K.R., Lu, H.C., Sharley, D.J., and Pettigrove, V. (2019). Associations between microplastic pollution and land use in urban wetland sediments. Environmental Science and Pollution Research 26, 22551-22561. 
Wang, T., Hu, M., Xu, G., Shi, H., Leung, J.Y.S., and Wang, Y. (2021). Microplastic accumulation via trophic transfer: Can a predatory crab counter the adverse effects of microplastics by body defence? Science $\begin{array}{llll}\text { of the Total Environment 754, } 142099 . & \end{array}$ https://doi.org/10.1016/j.scitotenv.2020.142099

Welden, N.A.C., and Cowie, P.R. (2016). Long-term microplastic retention causes reduced body condition in the langoustine, Nephrops norvegicus. Environmental Pollution 218, 895-900. https://doi.org/10.1016/j.envpol.2016.08.020

Woods, M.N., Stack, M.E., Fields, D.M., et al. (2018). Microplastic fiber uptake, ingestion, and egestion rates in the blue mussel (Mytilus edulis). Marine Pollution Bulletin 137, 638-645. https://doi.org/10.1016/j.marpolbul.2018.10.061

Xiong, X., Tu, Y., Chen, X., et al. (2019). Ingestion and egestion of polyethylene microplastics by gold fish (Carassius auratus): influence of color and morphological features. Heliyon 5, e03063. https://doi.org/10.1016/j.heliyon.2019.e03063

Yang, H., Xiong, H., Mi, K., et al. (2020). Toxicity comparison of nanosized and micron-sized microplastics to Gold fish Carassius auratus Larvae. Journal of Hazardous Materials 388, 122058. https://doi.org/10.1016/j.jhazmat.2020.122058

Yaranal, N.A., Subbiah, S., and Mohanty, K. (2021). Distribution and characterization of microplastics in beach sediments from Karnataka (India) coastal environments. Marine Pollution Bulletin 169, 112550. https://doi.org/10.1016/j.marpolbul.2021.112550

Yu, H., Zhang, X., Hu, J., Peng, J., and Qu, J. (2020). Ecotoxicity of polystyrene microplastics to submerged carnivorous Utricularia vulgaris plants in freshwater ecosystems. Environmental Pollution 265, 114830. https://doi.org/10.1016/j.envpol.2020.114830

Yu, J., Tian, J., Xu, R., et al. (2020). Effects of microplastics exposure on ingestion, fecundity, development, and dimethylsulfide production in Tigriopus japonicus (Harpacticoida, copepod). Environmental Pollution 267, 115429. https://doi.org/10.1016/j.envpol.2020.115429

Zhang, K., Hamidian, A. H., Tubić, A., et al. (2021). Understanding plastic degradation and microplastic formation in the environment: A $\begin{array}{lll}\text { review. } & \text { Environmental } & \text { Pollution } \\ \end{array}$ https://doi.org/10.1016/j.envpol.2021.116554

Zhang, P., Huang, P., Sun, H., et al. (2020). The structure of agricultural microplastics (PT, PU and UF) and their sorption capacities for PAHs and PHE derivates under various salinity and oxidation treatments. Environmental Pollution 257, 113525. https://doi.org/10.1016/j.envpol.2019.113525

Zhao, J., Fu, G., and Lei, K. (2015). Water Quality Assessment and Apportionment of Pollution Sources of Selected Pollutants in the Min Jiang, a Headwater Tributary of The Yangtze River. Journal of Waste Water Treatment and Analysis 6(03). https://doi.org/10.4172/21577587.1000211

Zhou, Q., Tu, C., Fu, C., et al. (2020). Characteristics and distribution of microplastics in the coastal mangrove sediments of China. Science of the Total Environment 703, 134807. https://doi.org/10.1016/j.scitotenv.2019.134807

Zhou, Z., Zhang, P., Zhang, G., Wang, S., Cai, Y., and Wang, H. (2021). Vertical microplastic distribution in sediments of Fuhe River estuary to Baiyangdian Wetland in Northern China. Chemosphere 280, 130800. https://doi.org/10.1016/j.chemosphere.2021.130800

Zimmermann, L., Sarah, G., Oehlmann, J., et al. (2020). What are the drivers of microplastic toxicity? Comparing the toxicity of plastic chemicals and particles to Daphnia magna. Environmental Pollution 267,115392 